\title{
RESPON TANAMAN SAWI HIJAU (Brassica parachinensis) TERHADAP PEMBERIAN DOSIS PUPUK KOMPOS DARI LIMBAH KULIT BUAH JARAK PAGAR (Jatropha curcas)
}

\author{
Oleh : \\ Melissa Syamsiah*) \\ Ramli*) \\ Wedi Nur Iman Akbar **) \\ Email : melissasyamsiah@gmail.com dan ramlijuned1664@gmail.com
}

\begin{abstract}
ABSTRAK
Sawi hijau (caisim) merupakan sayuran daun yang cukup populer di Indonesia sebagai pendamping masakan yang kaya nutrisi. Untuk memenuhi kebutuhan pasar, diperlukan upaya peningkatan produktivitas sawi hijau, salah satunya yaitu melalui pemupukan. Pemanfaatan kompos dari kulit buah jarak pagar (KJP) merupakan strategi pengelolaan limbah pertanian, sekaligus menciptakan alternatif pemupukan untuk meningkatkan produktivitas tanaman. Penelitian ini bertujuan untuk mengetahui pengaruh pemberian dosis pupuk kompos dari limbah KJP terhadap pertumbuhan dan hasil tanaman sawi hijau. Penelitian ini dilaksanakan pada bulan Maret hingga Juni 2020 dengan menggunakan rancangan acak kelompok (RAK) nonfaktorial. Tanaman diberikan perlakuan dosis pupuk kompos dari limbah KJP dengan empat taraf perlakuan, yaitu D0 (0 g/tanaman), D1 (100 g/tanaman), D2 (150 g/tanaman), dan D3 (200 g/tanaman). Parameter yang diamati meliputi tinggi tanaman, jumlah daun, luas daun, dan bobot basah tanaman sawi hijau. Hasil penelitian menunjukkan perlakuan dosis kompos berpengaruh secara signifikan terhadap seluruh parameter penelitian. Perlakuan D2 $(150 \mathrm{~g} /$ tanaman $)$ memberikan hasil terbaik dengan rerata tinggi tanaman $37.94 \mathrm{~cm}, 11.88$ helai daun, luas daun $1304.56 \mathrm{~cm}^{2}$, dan bobot basah rata-rata $138.33 \mathrm{~g}$.
\end{abstract}

Kata kunci: Sawi hijau (Brassica paracbinensis), Kompos, Kulit buah jarak pagar (Jatropha curcas).

ABSTRACT

Mustard greens (choy sum) is a nutrient-rich vegetable that is quite popular in Indonesia. Sustained efforts are required to maintain mustard crop productivity to meet market demands, one of which can be achieved through fertilization. Utilization of Jatropha curcas fruit hull (JFH) waste as compost fertilizer is a strategy to manage agricultural waste, while at the same time creating an alternative to fertilization to increase crop productivity. The purpose of this research was to determine the effect of several doses of JFH waste compost on the growth and yield of mustard greens. The research was conducted from March to June 2020 using a non-factorial randomized block design (RBD). The plants were subjected by four treatment levels of JFH waste compost, namely DO (0 g/plant), D1 (100 g/plant), D2 (150 g/plant), and D3 (200 $\mathrm{g} /$ plant). Parameters observed included the plant height, number of leaves, leaf area, and the fresh weight of mustard greens. The results showed that compost treatment significantly affected all parameters. The D2 treatment $(150 \mathrm{~g} /$ plant $)$ showed the best result with an average plant height of $37.94 \mathrm{~cm}, 11.88$ leaves, $1304.56 \mathrm{~cm}^{2}$ in leaf area, and $138.33 \mathrm{~g}$ for the average fresh weight.

Keywords: Mustard greens (Brassica parachinensis), Compost, Jatropha curcas fruit hull waste.

*) Dosen Fakultas Sains Terapan UNSUR.

**) Alumni Fakultas Sains Terapan UNSUR.

RESPON TANAMAN SAWI HIJAU (Brassica

MELISSA SYAMSIAH, RAMLI

parachinensis) TERHADAP PEMBERIAN

dan WEDI NUR IMAN AKBAR

KULIT BUAH JARAK PAGAR (Jatropha curcas) 


\section{PENDAHULUAN}

Kesadaran masyarakat terhadap asupan nutrisi untuk menjaga kesehatan tubuh semakin meningkat. Hal ini terlihat dari jumlah permintaan masyarakat terhadap produk pertanian yang bernilai gizi tinggi. Dalam hal tersebut, tanaman sayuran dari keluarga kubis-kubisan (Brassicaceae) memiliki popularitas yang cukup tinggi karena kandungan gizi serta khasiatnya sebagai antikanker, antioksidan dan antiinflamasi (Cartea et al., 2011).

Sawi hijau (Brassica parachinensis) merupakan salah satu tanaman sayuran dari keluarga Brassicaceae. Tanaman ini cukup populer di Indonesia dilihat dari peningkatan konsumsi sawi hijau nasional sebesar 3.5\% per kapita per tahun selama periode 2013-2018 (Pusdatin Pertanian, 2018). Sawi hijau sangat baik dikonsumsi untuk membantu memenuhi kebutuhan gizi yang seimbang. Di antara zat gizi yang terkandung di dalam sawi hijau yaitu karbohidrat, protein, vitamin A, vitamin $\mathrm{C}$, fosfor, kalsium, dan magnesium (Cartea et al., 2011).

Indonesia memiliki karakteristik iklim dan tanah yang sesuai untuk budi daya sawi hijau. Masa panen yang relatif singkat dan pasar yang terbuka luas menjadi daya tarik untuk mengusahakan tanaman ini (Indriyani et al., 2018). Lebih dari 210 ribu rumah tangga telah mengusahakan sawi hijau di Indonesia. Jumlah ini jauh lebih tinggi dibandingkan pengusahaan tanaman sejenisnya, seperti brokoli (23.192 rumah tangga), selada (12.440 rumah tangga), dan pakcoy (7.723 rumah tangga) (Sensus Pertanian, 2013).

Dalam mengusahakan komoditas pertanian, pemupukan menjadi salah satu faktor peting dalam mempertahankan produksi dan memenuhi permintaan pasar. Pada umumnya, petani cenderung menggunakan pupuk kimia sintetis (anorganik) karena dinilai lebih efektif dan praktis. Akan tetapi, penggunaan jangka panjang dapat menurunkan produktivitas lahan (Kurniawati, 2016). Oleh karena itu, pemanfaatan bahan organik dapat dilakukan untuk menjaga kesuburan lahan dan mengurangi kebutuhan pupuk kimia sintetis (Agustina et al., 2012).

Tanaman jarak pagar (Jatropha curcas) telah dikenal sebagai salah satu sumber bahan bakar alternatif (biodiesel) karena kandungan minyak yang tinggi pada bijinya, yaitu sekitar 35-45\%. Potensi tersebut juga didukung oleh karakteristik jarak pagar yang dapat dikembangkan di daerah kering dan lahan marginal (Santoso, 2010). Selain produksi minyak, hasil samping pengolahan minyak jarak juga berpotensi menghasilkan produk yang bermanfaat. Salah satu hasil samping tersebut adalah kulit buah jarak pagar yang menempati 30\% dari total proporsi buah (Primandari et al., 2018).

Menurut Lima et al. (2014), kulit buah jarak mengandung $12.9 \% \mathrm{~N}, 6.6 \% \mathrm{P}$, dan $70.8 \% \mathrm{~K}$ dari total nutrisi makro yang dapat diekstrak dari buah, sehingga limbah biomassa ini berpotensi untuk dijadikan pupuk kompos sebagai sumber kalium. Hal ini didukung oleh Suwarno (2011) yang menyatakan bahwa kompos dari limbah kulit buah jarak pagar telah memenuhi standar kualitas hara kompos, serta terbukti dapat 
meningkatkan kualitas pertumbuhan dan hasil tanaman jagung. Selain itu, kandungan unsur kalium yang tinggi menjadikan kompos ini potensial untuk mengurangi penggunaan pupuk kalium anorganik pada tanaman jagung manis (Arrasyid, 2016).

Potensi limbah kulit buah jarak pagar untuk dijadikan kompos cukup baik, di samping sebagai upaya pengelolaan limbah, kompos juga bermanfaat untuk memperbaiki kesuburan tanah dan meningkatkan produktivitas tanaman. Penelitian ini dilakukan untuk melihat pengaruh pemberian dosis pupuk kompos dari limbah kulit buah jarak pagar terhadap pertumbuhan dan produksi tanaman sawi hijau.

Berdasarkan latar balakang penelitian, dapat dirumuskan masalah yang dikaji dalam penelitian ini, yaitu bagaimana pengaruh dosis pupuk kompos dari limbah kulit buah jarak pagar terhadap pertumbuhan dan hasil tanaman sawi hijau, meliputi parameter tinggi tanaman, jumlah daun, luas daun, dan bobot basah.

\section{METODE PENELITIAN}

\section{Waktu dan Tempat}

Penelitian ini dilaksanakan di Kampung Cigalumpit, RT/RW 004/015 Desa Bojong, Kecamatan Karangtengah, Kabupaten Cianjur. Penelitian ini dimulai pada bulan Maret 2020 dan berakhir pada bulan Juni 2020.

\section{Alat dan Bahan}

Alat yang digunakan dalam penelitian ini yaitu tray semai 200 lubang, polybag berukuran $23 \times 12.5 \times 12.5 \mathrm{~cm}$, pressure sprayer, wadah plastik, saringan, ayakan kawat (mesh $6 \mathrm{~mm}$ ), cangkul, golok, gelas ukur, terpal plastik, karung, alat tulis, kamera, tripod, kain hitam, laptop, penggaris, timbangan digital, dan termo-higrometer HTC1.

Bahan pengomposan terdiri atas kulit buah jarak pagar (KJP), kotoran kambing $(20 \%)$, dan bahan organik lain (5\%) yang terdiri atas bonggol pisang, air kelapa muda, air cucian beras, larutan gula merah, dan bioaktivator EM4 Pertanian. Bahan tanam terdiri atas benih sawi hijau kultivar Tosakan, arang sekam, dan pupuk kandang sapi.

\section{Tahapan Penelitian}

Penelitian ini terdiri atas beberapa tahapan, yaitu pembuatan kompos dari limbah KJP, penyiapan bahan tanam, penyiapan media tanam (aplikasi perlakuan), penanaman, pemeliharaan tanaman dan panen. Tahapan penelitian secara terperinci adalah sebagai berikut:

1. Pembuatan kompos dari limbah KJP dilakukan dengan mencampurkan bahanbahan pengomposan dan diinkubasi selama 30 hari.

2. Penyiapan bahan tanam dilakukan dengan menyemai benih sawi hijau pada tray semai. Media semai yang digunakan adalah campuran tanah halus, arang sekam, dan pupuk kandang sapi dengan perbandingan 1:1:1. Setiap lubang semai diisi satu butir benih sawi hijau. Penyiraman dilakukan secara rutin untuk menjaga 
kelembapan media semai.

3. Penyiapan media tanam dilakukan dengan mencampurkan $1.5 \mathrm{~kg}$ tanah dengan kompos limbah KJP sesuai dosis perlakuan ke dalam polybag. Pencampuran dilakukan secara terpisah untuk setiap polybag dan disertai pelabelan. Setelah itu, media tanam didiamkan selama seminggu.

4. Penanaman dilakukan dengan memindahkan bibit sawi hijau berumur 12 hari setelah semai pada media tanam yang telah disiapkan. Setelah itu, tanaman sawi diletakkan sesuai denah percobaan (Gambar 3.1), kemudian disiram secukupnya.

5. Pemeliharaan tanaman meliputi penyiraman, sanitasi lingkungan, dan pengendalian organisme pengganggu tanaman (OPT). Sanitasi lingkungan dan pengendalian OPT dilakukan setiap pagi dan sore hari, sedangkan penyiraman tanaman disesuaikan dengan kondisi cuaca.

6. Panen dilakukan saat tanaman sawi hijau berumur 35 hari setelah tanam. Polybag dilepaskan dengan hati-hati untuk mengurangi kerusakan akar tanaman serta memudahkan pembersihan akar tanaman dari tanah dan kotoran. Setelah dibersihkan, sawi hijau dicuci dengan air bersih dan ditiriskan.

\section{Teknik Pengumpulan Data}

Parameter yang diukur dalam penelitian ini terdiri atas tinggi tanaman, jumlah daun, luas daun, dan bobot basah tanaman sawi hijau. Pengukuran tinggi tanaman dan jumlah daun dilakukan setiap tujuh hari sejak masa tanam hingga 35 hari setelah tanam (panen). Parameter luas daun dan bobot basah hanya diukur pada saat pascapanen. Berikut ini adalah metode pengukuran yang digunakan:

1. Tinggi tanaman diukur dari pangkal batang di atas permukaan tanah hingga ujung daun tertinggi menggunakan penggaris. Hasil pengukuran dicatat dalam satuan sentimeter $(\mathrm{cm})$.

2. Jumlah daun dihitung secara manual dengan menghitung jumlah daun yang telah terbuka penuh dan masih berwarna hijau.

3. Luas daun dihitung dengan metode Leaf Image Analysis: Surface Area menggunakan kamera dan aplikasi Photoshop CS6 (penjelasan mengenai metode ini terdapat pada Lampiran 3). Hasil pengukuran dicatat dalam satuan sentimeter persegi $\left(\mathrm{cm}^{2}\right)$.

4. Bobot basah diperoleh dengan menimbang tanaman utuh menggunakan timbangan digital. Hasil penimbangan dicatat dalam satuan gram (g).

\section{Rancangan Percobaan}

Penelitian ini menggunakan Rancangan Acak Kelompok (RAK) non faktorial dengan satu faktor perlakuan, yaitu dosis pupuk kompos dari limbah KJP. Dosis perlakuan terdiri atas 4 taraf (Tabel 1). Setiap perlakuan terdiri atas 6 kelompok, sehingga menghasilkan 24 satuan percobaan, dan setiap satuan percobaan terdapat 3 sampel tanaman. 
Tabel 1. Dosis Perlakuan Kompos Dari Limbah KJP.

\begin{tabular}{ccc}
\hline Perlakuan & Dosis & Konversi \\
\hline D0 (kontrol) & 0 ton $/ \mathrm{ha}$ & $0 \mathrm{~g} /$ tanaman \\
D1 & $20 \mathrm{ton} / \mathrm{ha}$ & $100 \mathrm{~g} / \operatorname{tanaman}$ \\
D2 & $30 \mathrm{ton} / \mathrm{ha}$ & $150 \mathrm{~g} / \operatorname{tanaman}$ \\
D3 & $40 \mathrm{ton} / \mathrm{ha}$ & $200 \mathrm{~g} / \operatorname{tanaman}$ \\
\hline
\end{tabular}

Keterangan: Dosis KJP, D0 $=0 \mathrm{~g} / \operatorname{tanaman}(\mathrm{kontrol}), \mathrm{D} 1=100 \mathrm{~g} /$ tanaman, $\mathrm{D} 2=150 \mathrm{~g} / \tan a m a n, \mathrm{D} 3=200 \mathrm{~g} /$ tanaman .

\section{HASIL DAN PEMBAHASAN}

\section{Tinggi Tanaman}

Tinggi tanaman merupakan parameter yang mudah untuk diamati sebagai indikator pengaruh lingkungan terhadap pertumbuhan tanaman. Berdasarkan hasil sidik ragam pada taraf signifikansi 5\%, perlakuan dosis kompos limbah KJP menunjukkan pengaruh yang signifikan terhadap parameter tinggi tanaman dengan nilai sig. $0.00<\alpha 5 \%$. Oleh karena itu, dilakukan uji lanjut DMRT pada taraf signifikansi $5 \%$ untuk melihat jenis perlakuan dosis kompos yang berbeda nyata. Hasil pengamatan terhadap rerata tinggi tanaman sawi hijau beserta hasil uji lanjut DMRT disajikan pada Gambar 1.

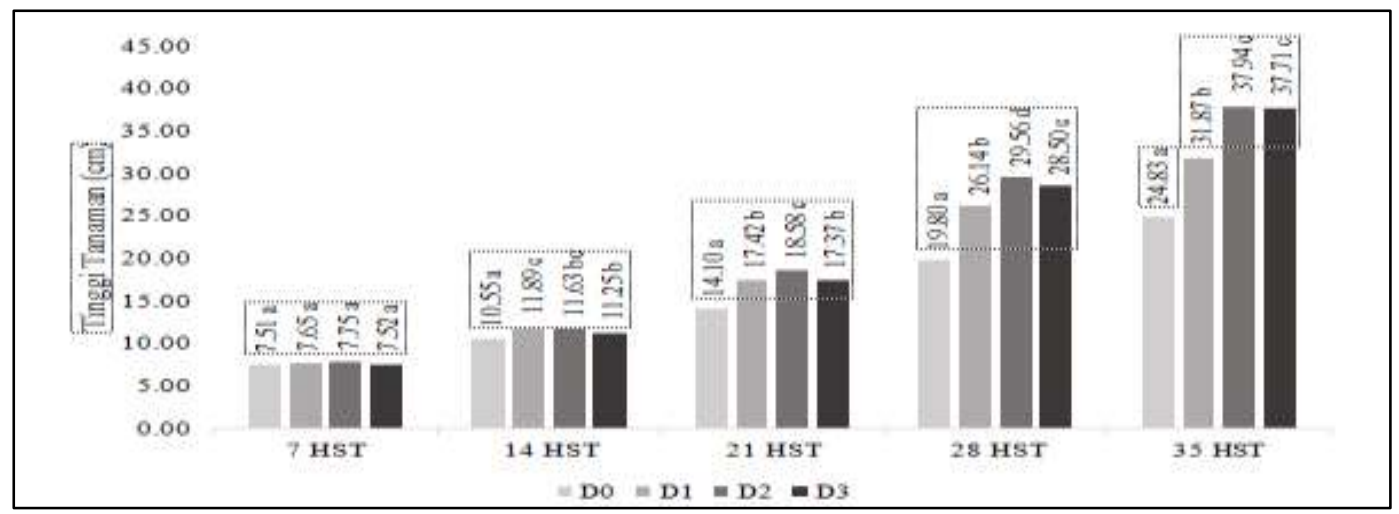

Gambar 1. Grafik rerata tinggi tanaman sawi hijau.

Keterangan : Angka yang diikuti huruf yang sama pada kategori waktu yang tidak berbeda nyata pada uji lanjut DMRT 5\%. D0 $=0 \mathrm{~g} / \tan a m a n$ (kontrol), D1 $=100 \mathrm{~g} / \operatorname{tanaman}, \mathrm{D} 2=$ $150 \mathrm{~g} /$ tanaman, D3 = $200 \mathrm{~g} /$ tanaman. HST $=$ Hari Setelah Tanam.

Secara umum, perlakuan dosis pupuk kompos dari limbah KJP memberikan pengaruh yang lebih baik terhadap parameter tinggi tanaman dibandingkan perlakuan kontrol (tanpa kompos). Pertambahan tinggi tanaman sawi relatif sejalan dengan peningkatan dosis kompos.

Hasil pengamatan pada 7 HST menunjukkan perlakuan dosis kompos belum memberikan pengaruh yang signifikan terhadap tinggi tanaman sawi. Berdasarkan uji lanjut DMRT 5\%, perlakuan D2 (150 g/tanaman) menunjukkan rerata tinggi tanaman terbaik, yaitu $7.75 \mathrm{~cm}$. Hasil ini tidak berbeda nyata dengan perlakuan D1 
(100 g/tanaman) dengan tinggi rata-rata $7.65 \mathrm{~cm}$, perlakuan D3 (200 g/tanaman) dengan tinggi rata-rata $7.52 \mathrm{~cm}$, dan perlakuan kontrol (tanpa kompos) dengan tinggi rata-rata $7.51 \mathrm{~cm}$. Hal ini diduga karena hingga 7 HST kandungan hara pada seluruh media tanam masih mencukupi kebutuhan tanaman sawi.

Belum terlihatnya pengaruh perlakuan dosis kompos limbah KJP juga dapat disebabkan oleh nilai rasio $\mathrm{C} / \mathrm{N}$ kompos yang tinggi, sehingga laju mineralisasi bahan organik terhambat (Diaz dan Savage, 2007). Hal ini terlihat pada hasil pengamatan 14 HST, peningkatan dosis kompos cenderung menunjukkan pertumbuhan yang terhambat.

Berdasarkan uji lanjut DMRT 5\% pada hasil pengamatan 14 HST, perlakuan D1 (100 g/tanaman) menunjukkan rerata tinggi tanaman terbaik, yaitu

$11.89 \mathrm{~cm}$. Hasil ini berbeda nyata dengan perlakuan D2 (150 g/tanaman) dengan tinggi rata-rata $11.63 \mathrm{~cm}$, perlakuan D3 (200 g/tanaman) dengan tinggi rata-rata $11.25 \mathrm{~cm}$, dan perlakuan kontrol (tanpa kompos) dengan tinggi rata-rata $10.55 \mathrm{~cm}$.

Kulit buah jarak pagar terdiri atas 34\% selulosa, 10\% hemiselulosa, dan 12\% lignin (Gudeta, 2016). Proses pengomposan dengan rasio $\mathrm{C} / \mathrm{N}$ yang tinggi akan memakan waktu yang relatif lama, terutama jika bahan utamanya mengandung selulosa yang tinggi (Dwiyanty, 2011). Meski telah melalui proses pengomposan, nilai rasio $\mathrm{C} / \mathrm{N}$ limbah KJP masih terbilang tinggi.

Rasio $\mathrm{C} / \mathrm{N}$ merupakan perbandingan massa karbon (C) terhadap massa nitrogen $(\mathrm{N})$ di dalam suatu substansi. Pada umumnya, mikroorganisme tanah membutuhkan rasio $\mathrm{C} / \mathrm{N}$ mendekati 24 , terdiri atas 16 bagian untuk pembentukan energi (respirasi) dan 8 bagian untuk mempertahankan tubuhnya. Ketika rasio C/N bahan organik lebih tinggi dari 24, mikroorganisme akan menggunakan setiap $\mathrm{N}$ tersedia di dalam tanah untuk mendekomposisi bahan organik (imobilisasi). Keadaan ini dapat menyebabkan defisit $\mathrm{N}$ hingga proses mineralisasi bahan organik mengembalikan unsur N ke dalam tanah (NRCS, 2011).

Imobilisasi hara akibat pemberian bahan organik hanya berlangsung sementara karena proses mineralisasi tetap berjalan seiring waktu (Kurniawati, 2016). Selain itu, penambahan kompos tidak hanya mempengaruhi kualitas hara tanah, salah satu manfaat kompos lainnya yaitu dapat memperbaiki kualitas fisik tanah. Bahan organik mampu mengikat butir-butir tanah sehingga tanah menjadi gembur dan memudahkan penetrasi akar tanaman (Fauziah, 2011). Dengan struktur tanah yang baik, difusi oksigen (aerasi) ke dalam tanah juga menjadi lebih baik, sehingga dapat mendukung proses fisiologi akar (Setyorini et al., 2006).

Seperti terlihat pada hasil pengamatan 21 HST, terjadi peningkatan tinggi tanaman yang signifikan pada perlakuan D2 (150 g/tanaman). Berdasarkan hasil uji lanjut DMRT 5\%, perlakuan D2 (150 g/tanaman) menunjukkan rerata tinggi tanaman terbaik, yaitu $18.58 \mathrm{~cm}$. Hasil ini berbeda nyata dengan perlakuan D1 (100 $\mathrm{g} /$ tanaman) dengan tinggi rata-rata $17.42 \mathrm{~cm}$, perlakuan D3 (200 g/tanaman) dengan tinggi rata-rata $14.37 \mathrm{~cm}$, dan perlakuan kontrol (tanpa kompos) dengan tinggi ratarata $14.10 \mathrm{~cm}$. 
Hasil pengamatan pada 21 HST membuktikan karakteristik kompos yang lambat dalam melepas unsur hara ke dalam tanah, sehingga pengaruhnya tidak langsung terlihat pada awal pertanaman (Kurniawati, 2016). Bahan organik akan termineralisasi seiring waktu dan mengembalikan sejumlah hara yang terkandung di dalamnya. Sebagaimana bahan baku kompos berasal dari biomassa tumbuhan yang menyerap unsur hara, hasil mineralisasi biomassa ini juga mengandung unsur hara yang dibutuhkan tanaman (Wahyono, 2010).

Dengan karakteristik kompos yang lambat dalam melepaskan unsur hara sekaligus memperbaiki struktur tanah, maka akan tercipta suatu kondisi dimana sistem perakaran tanaman berkembang dengan baik dan mineralisasi bahan organik yang terus menyuplai unsur hara ke dalam tanah. Keadaan ini juga didukung oleh kemampuan kompos yang dapat mengikat air lebih lama dibandingkan dengan media tanam tanpa kompos, sehingga ketersediaan unsur hara untuk tanaman dapat terjamin pada saat diperlukan. Hal ini dikarenakan penyerapan unsur hara sangat bergantung pada ketersediaan air di dalam tanah (Kurniawati, 2016).

Kondisi tersebut terus berlanjut hingga pengamatan 28 HST dan 35 HST. Hasil pengamatan menunjukkan perlakuan dosis kompos memberikan pengaruh yang signifikan terhadap tinggi tanaman sawi dibandingkan perlakuan kontrol (tanpa kompos). Berdasarkan hasil pengamatan $28 \mathrm{HST}$, perlakuan D2 (150 g/tanaman) menunjukkan rerata tinggi tanaman terbaik, yaitu $29.56 \mathrm{~cm}$. Hasil ini berbeda nyata dengan perlakuan D1 (100 g/tanaman) dengan tinggi rata-rata $26.14 \mathrm{~cm}$, perlakuan D3 (200 g/tanaman) dengan tinggi rata-rata $28.50 \mathrm{~cm}$, dan perlakuan kontrol (tanpa kompos) dengan tinggi rata-rata $19.80 \mathrm{~cm}$.

Pengamatan pada 35 HST juga menunjukkan hasil yang serupa. Perlakuan D2 (150 g/tanaman) menunjukkan rerata tinggi tanaman terbaik, yaitu $37.94 \mathrm{~cm}$. Hasil ini tidak berbeda nyata dengan perlakuan D3 (200 g/tanaman) dengan tinggi rata-rata $37.71 \mathrm{~cm}$. Akan tetapi, kedua perlakuan tersebut berbeda nyata dengan perlakuan D1 (100 g/tanaman) dengan tinggi rata-rata $31.87 \mathrm{~cm}$, dan perlakuan kontrol (tanpa kompos) dengan tinggi rata-rata $24.83 \mathrm{~cm}$.

Hasil pengamatan pada 28 HST dan 35 HST menunjukkan peningkatan rerata tinggi tanaman yang signifikan pada perlakuan D3 (200 g/tanaman). Peningkatan tersebut diduga dipengaruhi oleh proses mineralisasi bahan organik yang terus berlangsung seiring waktu, sehingga kebutuhan unsur hara masih dapat terpenuhi. Sementara itu, perlakuan D1 (100 g/tanaman) dan perlakuan D2 (150 g/tanaman) menunjukkan terjadinya penurunan kandungan bahan organik, sehingga ketersediaan unsur hara mulai menurun. Hal ini ditandai dengan laju pertumbuhan tanaman yang melambat. Menurut Kurniawati (2018), sawi hijau merupakan tanaman yang responsif terhadap kondisi hara di dalam tanah, sehingga gejala kekurangan atau kelebihan unsur hara akan mudah dikenali secara visual. Pengaruh perlakuan dosis kompos limbah KJP terhadap tinggi tanaman sawi dapat diamati pada Lampiran 8.

Nitrogen $(\mathrm{N})$, fosfor $(\mathrm{P})$, dan kalium $(\mathrm{K})$ merupakan unsur hara esensial yang memegang peranan penting dalam metabolisme tanaman. Jika ketersediaan hara 
esensial kurang dari jumlah yang dibutuhkan tanaman, maka proses metabolisme dan pertumbuhan tanaman akan terhambat. Gejala kekurangan hara dapat dikenali secara visual berupa pertumbuhan akar, batang, dan daun yang terhambat (kerdil), timbulnya gejala klorosis (kerusakan klorofil) dan/atau nekrosis (jaringan mati) pada organ tanaman tertentu (Lakitan, 2015). Dengan penambahan kompos, unsur hara esensial dapat diserap oleh tanaman setelah melalui proses mineralisasi oleh mikroorganisme (McGrath et al., 2014).

Nitrogen diserap tanaman dalam bentuk ion nitrat $\left(\mathrm{NO}^{-}\right)$dan/atau amonium $\left(\mathrm{NH}_{4}{ }^{+}\right)$. Nitrogen merupakan komponen penting dalam asam amino, protein, asam nukleat (DNA dan RNA), klorofil, dan enzim (Mitra, 2015). Berdasarkan hasil penelitian Astria dan Suntari (2017), semakin tinggi ketersediaan N di dalam tanah, semakin tinggi pula serapan $\mathrm{N}$ oleh tanaman sawi. Oleh karena itu, sumbangan $\mathrm{N}$ dari kompos dapat mempegaruhi tingkat serapan $\mathrm{N}$ oleh tanaman. Nitrogen akan digunakan untuk berbagai proses metabolik, terutama fotosintesis. Sebagian hasil fotosintesis (fotosintat) akan digunakan untuk pertumbuhan dan perkembangan organ-organ tanaman seperti batang dan daun. Kekurangan unsur $\mathrm{N}$ akan menghambat pertumbuhan vegetatif, tanaman menjadi kerdil, dan terjadi gejala klorosis pada daun-daun tua (Fauziah, 2011).

Fosfor diserap tanaman dalam bentuk ion $\mathrm{HPO}_{4}{ }^{2-}$ dan/atau ion $\mathrm{H}_{2} \mathrm{PO} 4^{-}$. Fosfor merupakan komponen penting dalam molekul nukleotida (DNA dan RNA) yang berperan dalam sintesis protein. Selain itu, fosfor merupakan komponen penting dari molekul-molekul yang berperan dalam penyimpanan dan transfer energi dalam reaksi metabolik, seperti ADP (Adenosine diphosphate) dan ATP (Adenosine triphosphate) (Mitra, 2015).

Pada kondisi tertentu, konsentrasi fosfor sangat rendah di dalam tanah, bahkan dapat lebih rendah dibandingkan konsentrasi fosfor di dalam sel akar (Mitra, 2015). Pada kondisi tanah seperti ini, tanaman akan beradaptasi dengan meningkatkan jangkauan dan luas bidang penyerapan akar terhadap unsur P. Hal ini mengakibatkan tanaman menggunakan asimilat dan energi yang lebih tinggi pada pertumbuhan akar dibandingkan pertumbuhan tajuk, sehingga pertumbuhan tajuk menjadi terhambat (kerdil) (Lynch et al., 2012).

Kalium diserap tanaman dalam bentuk ion $\mathrm{K}^{+}$. Kalium berperan dalam berbagai reaksi enzimatis dalam metabolisme tanaman seperti fotosintesis dan respirasi, serta berperan dalam pembentukan protein dan karbohidrat. Kalium juga berfungsi dalam mengatur potensial osmotik dan turgor sel yang erat kaitannya dengan pergerakan air, translokasi asimilat, kinerja stomata, serta menjaga tegakan tubuh tanaman tetap kuat (Lakitan, 2015; Apriliani et al., 2016). Kekurangan unsur hara $\mathrm{K}$ akan menghambat laju fotosintesis dan mempengaruhi distribusi asimilat menuju akar dan tajuk tanaman, yang pada akhirnya akan menghambat pertumbuhan tanaman. Selain itu, tanaman mudah rebah dan rentan terhadap serangan penyakit (Grzebisz et al., 2013). 
Secara umum, laju pertumbuhan tanaman yang terhambat terlihat pada perlakuan kontrol (tanpa kompos). Berkaitan dengan tinggi tanaman, gejala yang tampak secara visual yaitu tinggi dan volume tanaman yang lebih rendah dibandingkan perlakuan kompos. Hal ini menandakan proses metabolik tanaman yang terganggu akibat kekurangan unsur hara, sehingga pembelahan sel, pembentukan jaringan, dan perkembangan organ-organ tanaman menjadi terhambat (Grzebisz et al., 2013).

\section{Jumlah Daun}

Pertumbuhan dan perkembangan tanaman dipengaruhi oleh kemampuan tanaman dalam melakukan fotosintesis. Daun merupakan tempat berlangsungnya fotosintesis, sehingga jumlah daun dapat menentukan kapasitas tanaman dalam melakukan proses tersebut.

Berdasarkan hasil sidik ragam pada taraf signifikansi 5\%, perlakuan dosis kompos limbah KJP menunjukkan pengaruh yang signifikan terhadap parameter jumlah daun tanaman sawi dengan nilai sig. $0.00<\alpha 5 \%$. Oleh karena itu, dilakukan uji lanjut DMRT pada taraf signifikansi 5\% untuk melihat jenis perlakuan dosis kompos yang berbeda nyata. Hasil pengamatan terhadap rerata jumlah daun tanaman sawi hijau beserta hasil uji lanjut DMRT disajikan pada Gambar 2.

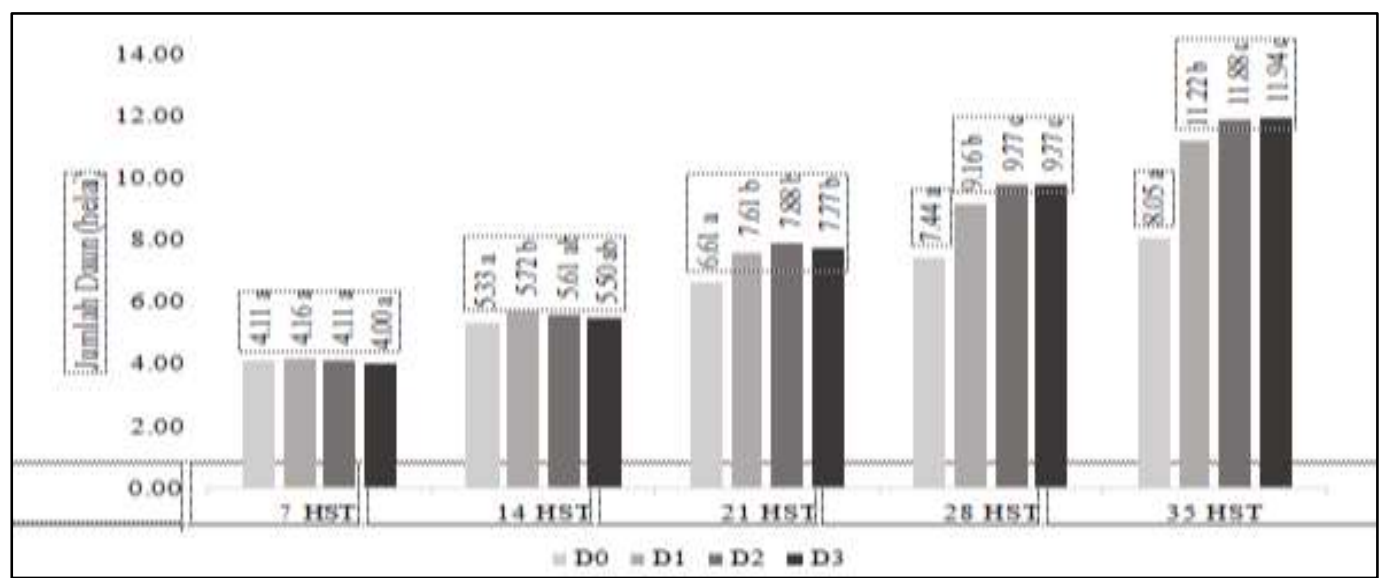

Gambar 2. Grafik rerata jumlah daun tanaman sawi hijau.

Keterangan : Angka yang diikuti huruf yang sama pada kategori waktu yang tidak berbeda nyata pada uji lanjut DMRT 5\%. D0 $=0 \mathrm{~g} / \tan a m a n$ (kontrol), D1 $=100 \mathrm{~g} / \operatorname{tanaman}, \mathrm{D} 2=$ $150 \mathrm{~g} /$ tanaman, D3 = $200 \mathrm{~g} /$ tanaman. HST $=$ Hari Setelah Tanam.

Secara umum, perlakuan dosis pupuk kompos dari limbah KJP memberikan pengaruh yang lebih baik terhadap parameter jumlah daun dibandingkan perlakuan kontrol (tanpa kompos). Pertambahan jumlah daun tanaman sawi relatif sejalan dengan peningkatan dosis kompos.

Hasil pengamatan pada 7 HST menunjukkan perlakuan dosis kompos belum memberikan pengaruh yang signifikan. Berdasarkan uji lanjut DMRT 5\%, perlakuan 
D1 (100 g/tanaman) menunjukkan rerata jumlah daun terbaik, yaitu 4.16 helai. Hasil ini tidak berbeda nyata dengan perlakuan D2 (150 g/tanaman) dengan jumlah daun rata-rata 4.11 helai, perlakuan D3 (200 g/tanaman) dengan jumlah daun rata-rata 4.10 helai, dan perlakuan kontrol (tanpa kompos) dengan jumlah daun rata-rata 4.00 helai. Hal ini menunjukkan ketersediaan hara pada seluruh media tanam masih mencukupi kebutuhan tanaman sawi. Kondisi ini juga berkaitan dengan laju mineralisasi bahan organik yang terhambat.

Menurut Hairiah et al. (2002), pada tanaman semusim yang dipupuk dengan bahan organik, jumlah hara yang dapat diserap oleh tanaman relatif sedikit. Hal ini dapat disebabkan oleh sinkronisasi yang rendah antara waktu tersedianya unsur hara dengan kebutuhan tanaman. Dalam hal ini, tanaman sawi pada fase vegetatif membutuhkan unsur hara dalam jumlah banyak, sedangkan bahan organik belum termineralisasi dengan baik, sehingga unsur hara (terutama $\mathrm{N}$ ) di dalam kompos belum tersedia untuk tanaman.

Hal serupa juga terlihat pada pengamatan 14 HST. Hasil pengamatan menunjukkan bahwa perlakuan dosis kompos memberikan pengaruh yang signifikan dibandingkan perlakuan kontrol (tanpa kompos). Akan tetapi, peningkatan dosis kompos cenderung menunjukkan pertumbuhan yang terhambat.

Berdasarkan uji lanjut DMRT 5\%, perlakuan D1 (100 g/tanaman) menunjukkan rerata jumlah daun terbaik, yaitu 5.72 helai. Hasil ini tidak berbeda nyata dengan perlakuan D2 (150 g/tanaman) dengan jumlah daun rata-rata 5.61 helai, dan perlakuan D3 (200 g/tanaman) dengan jumlah daun rata-rata 5.50 helai. Akan tetapi, ketiga perlakuan kompos tersebut berbeda nyata dengan perlakuan kontrol (tanpa kompos) dengan jumlah daun rata-rata 5.33 helai.

Kompos limbah KJP mengandung 1-4\% N, 0.1-0.7\% P, dan 5-14\% K. Pemberian dosis kompos sebanyak 20 ton/ha (100 g/tanaman) diperkirakan dapat menyumbang hara sebesar 1-4 g N, 0.1-0.7 g P, dan 5-14 g K per tanaman (Wahyono, 2010). Secara teknis, jumlah tersebut telah memenuhi kebutuhan pemupukan tanaman sawi hijau (BPTP Jambi, 2009). Akan tetapi, mengingat karakteristik kompos yang lambat dalam pelepasan hara, maka jumlah hara yang dapat diserap tanaman tergantung pada laju mineralisasi bahan organik (Setyorini et al., 2006). Berdasarkan hal tersebut, laju mineralisasi bahan organik pada pengamatan 14 HST masih terbilang rendah, terutama pada dosis kompos yang lebih tinggi.

Pada pengamatan 21 HST, terjadi peningkatan laju pertumbuhan jumlah daun yang signifikan pada perlakuan D2 (150 g/tanaman) dan perlakuan D3 (200 $\mathrm{g} /$ tanaman). Berdasarkan hasil uji lanjut DMRT 5\%, perlakuan D2 (150 g/tanaman) menunjukkan rerata jumlah daun terbaik yaitu 7.88 helai. Hasil ini tidak berbeda nyata dengan perlakuan D1 (100 g/tanaman) dengan jumlah daun rata-rata 7.61 helai, dan perlakuan D3 (200 g/tanaman) dengan jumlah daun rata- rata 7.77 helai. Akan tetapi, ketiga perlakuan tersebut berbeda nyata dibandingkan perlakuan kontrol (tanpa kompos) dengan jumlah daun rata-rata 6.61 helai. Peningkatan laju pertumbuhan tersebut diduga berkaitan dengan laju mineralisasi bahan organik yang 
mulai meningkat.

Ketersediaan hara di dalam tanah tidak hanya bergantung pada laju mineralisasi bahan organik, karakteristik tanah sebagai media tanam juga perlu diperhatikan. Jenis tanah yang digunakan pada penelitian ini adalah tanah latosol. Secara umum, tanah latosol memiliki kandungan liat $\geq 60 \%$, struktur tanah remah dengan warna merah atau cokelat kemerahan, kandungan mineral primer dan hara yang rendah, bahan organik relatif rendah, $\mathrm{pH}$ tanah 4.5-5.5, kejenuhan basa $<50 \%$, dan kapasitas tukar kation (KTK) yang rendah yaitu $<24$ meq/100 g. Jika dilihat dari karakteristik tersebut, tingkat kesuburan tanah latosol tergolong rendah (Fauziah, 2011; Subardja et al., 2014).

Pemberian kompos menjadi salah satu upaya untuk meningkatkan kesuburan tanah dengan memperbaiki kualitas fisik, kimia, dan biologi tanah. Kompos limbah KJP memiliki kandungan C-organik yang cukup tinggi (17-45\%) yang berperan sebagai sumber energi untuk aktivitas mikroorganisme tanah (Diaz dan Savage, 2007; Sharma et al., 2009; Suwarno, 2011). Selain itu, kompos limbah KJP bersifat alkali, sehingga dapat digunakan untuk meningkatkan $\mathrm{pH}$ tanah latosol (Primandari et al., 2018).

Kompos limbah KJP juga mengandung koloid humus (14-20\%) yang berperan penting dalam mengikat kation-kation dan pembentukan agregat tanah, sehingga kapasitas tukar kation (KTK) tanah meningkat (Hairiah et al., 2002; Sharma et al., 2009). KTK asam-asam organik dari kompos lebih tinggi dibandingkan mineral liat, yaitu mencapai 485-870 meq/100 g (asam humat). Kondisi tersebut memungkinkan kation-kation hara seperti kalsium $\left(\mathrm{Ca}^{2+}\right)$, magnesium $\left(\mathrm{Mg}^{2+}\right)$, dan kalium $\left(\mathrm{K}^{+}\right)$dapat terikat pada koloid humus dan meningkatkan hara tersedia untuk tanaman (Setyorini et al., 2006).

Kandungan asam-asam organik pada kompos juga dapat mengundang mikroorganisme rizosfer seperti bakteri penambat $\mathrm{N}$, bakteri pelarut $\mathrm{P}$, serta bakteri siderophore (pengelat $\mathrm{Fe}^{3+}$ ) yang bermanfaat dalam proses mineralisasi hara di dalam tanah (Marschner, 2012). Selain itu, kompos dapat meningkatkan agregasi, permeabilitas, dan kapasitas buffer tanah, sehingga dapat mendukung penyerapan unsur hara oleh tanaman (Wahyono, 2010).

Kondisi tersebut terus berlanjut hingga pengamatan 28 HST dan 35 HST. Hasil pengamatan menunjukkan bahwa perlakuan dosis kompos memberikan pengaruh yang signifikan terhadap jumlah daun tanaman sawi dibandingkan perlakuan kontrol (tanpa kompos). Berdasarkan hasil uji lanjut DMRT 5\% pada pengamatan 28 HST, rerata jumlah daun terbaik diperoleh dari perlakuan D2 (150 g/tanaman) dan perlakuan D3 (200 g/tanaman) dengan jumlah daun rata-rata yang sama, yaitu 9.77 helai. Hasil ini berbeda nyata dengan perlakuan D1 (100 g/tanaman) dengan jumlah daun rata-rata 9.16 helai, dan perlakuan kontrol (tanpa kompos) dengan jumlah daun rata-rata 7.44 helai.

Pada pengamatan 35 HST, perlakuan D3 (200 g/tanaman) menunjukkan rerata jumlah daun terbaik, yaitu 11.94 helai. Hasil ini tidak berbeda nyata dengan perlakuan 
D2 (150 g/tanaman) dengan jumlah daun rata-rata 11.88 helai. Akan tetapi, kedua perlakuan tersebut berbeda nyata dengan perlakuan D1 (100 g/tanaman) dengan jumlah daun rata-rata 11.22 helai, dan perlakuan kontrol (tanpa kompos) dengan jumlah daun rata-rata 8.05 helai.

Hasil pengamatan pada 28 HST dan 35 HST menunjukkan peningkatan rerata jumlah daun yang signifikan pada perlakuan D3 (200 g/tanaman). Hal ini disebabkan oleh proses mineralisasi bahan organik yang terus berlangsung seiring waktu, sehingga kebutuhan unsur hara masih dapat terpenuhi. Selain itu, karakteristik kompos limbah KJP diduga memiliki kesesuaian dengan karakteristik tanah latosol, sehingga perlakuan kompos dinilai mampu memperbaiki kesuburan tanah dan menyediakan unsur hara untuk mendukung pertumbuhan tanaman.

Nitrogen merupakan unsur hara esensial yang sangat berperan dalam pertumbuhan vegetatif tanaman. Tanaman menggunakan $\mathrm{N}$ sebagai komponen pembentuk asam amino dan asam nukleat, dimana keduanya merupakan dasar pembentukan senyawa organik seperti protein, enzim, dan klorofil yang berperan dalam proses fotosintesis (McGrath et al., 2014).

Kekurangan unsur $\mathrm{N}$ dapat menyebabkan ekspansi daun terhambat (daun sempit) dan degradasi kloroplas (klorosis) pada daun tua, sehingga kapasitas fotosintesis menurun. Selain itu, jika ketersediaan $\mathrm{N}$ di dalam tanah kurang, tanaman akan meningkatkan pertumbuhan akar untuk memperluas bidang penyerapan akar terhadap unsur N. Hal ini mengakibatkan alokasi asimilat yang lebih besar untuk pertumbuhan akar, sehingga pertumbuhan tajuk menjadi terhambat (Mitra, 2017; Weissert dan Kehr, 2017).

Fosfor berperan dalam aktivitas penyimpanan dan transfer energi di dalam tanaman dalam bentuk ADP dan ATP. Selain itu, gula fosfat merupakan komponen struktural penting dari molekul DNA dan RNA, yaitu penyusun materi genetik yang bertanggung jawab dalam pertumbuhan dan perkembangan tanaman (McGrath et al., 2014). Peran unsur P dalam pembelahan sel melalui nukleoprotein memungkinkan pertumbuhan dan perkembangan organ-organ tanaman berlangsung normal. Kekurangan unsur $\mathrm{P}$ dapat menghambat pertumbuhan dan ekspansi daun, penurunan jumlah daun, dan menurunkan aktivitas fotosintesis (Mitra, 2017; Weissert dan Kehr, 2017).

Selain nitrogen, kalium ditemukan di dalam jaringan tanaman dengan konsentrasi yang lebih tinggi dibandingkan unsur lainnya (kecuali unsur struktural dasar $\mathrm{C}, \mathrm{H}$, dan $\mathrm{O}$ ). Karena sifatnya yang mobil, unsur $\mathrm{K}$ bertanggung jawab dalam status air di dalam tanaman, terutama dalam regulasi osmotik di dalam sel. Kekurangan unsur $\mathrm{K}$ akan terlihat pada tepian daun tua yang mengering kemudian gugur (McGrath et al., 2014). Hal ini disebabkan oleh remobilisasi unsur K dari daundaun tua ke organ-organ tanaman yang tumbuh aktif (meristem). Gejala tersebut merupakan salah satu mekanisme tanaman dalam meningkatkan efisiensi penggunaan unsur hara yang terbatas di dalam tanah (Mitra, 2017).

Secara umum, laju pertumbuhan tanaman yang terhambat terlihat pada 
perlakuan kontrol (tanpa kompos). Berkaitan dengan jumlah daun, gejala yang tampak di lapangan yaitu jumlah daun yang gugur (senescence) lebih banyak dibandingkan perlakuan kompos. Pada kondisi defisit hara, tanaman cenderung meningkatkan rasio akar/tajuk untuk meningkatkan efisiensi serapan hara, sehingga pertumbuhan tajuk terhambat (Lynch et al., 2012). Selain itu, terjadi remobilisasi unsur hara yang bersifat mobil seperti N, P, dan K dari daun tua ke daun muda atau organ reproduktif (Lakitan, 2015).

\section{Luas Daun}

Daun merupakan tempat berlangsungnya fotosintesis, sehingga luas daun dapat menentukan kapasitas tanaman dalam melakukan proses tersebut. Oleh karena itu parameter luas daun dapat digunakan sebagai indikator pertumbuhan dan produksi tanaman sawi hijau.

Berdasarkan hasil sidik ragam pada taraf signifikansi $5 \%$, perlakuan dosis kompos limbah KJP menunjukkan pengaruh yang signifikan terhadap parameter luas daun dengan nilai sig. $0.00<\alpha 5 \%$. Berdasarkan hasil tersebut, dilakukan uji lanjut DMRT pada taraf signifikansi 5\% untuk melihat jenis perlakuan dosis kompos yang berbeda nyata. Hasil pengamatan terhadap rerata luas daun tanaman sawi hijau beserta hasil uji lanjut DMRT disajikan pada Gambar 3.

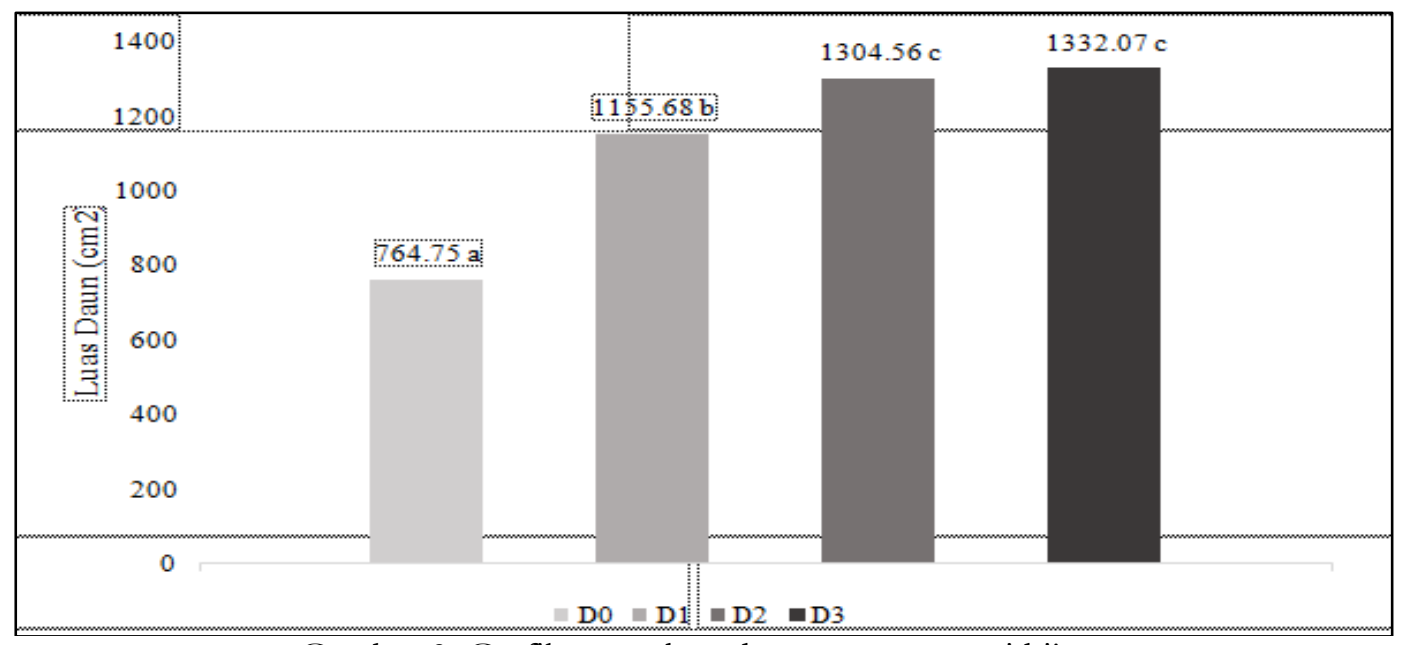

Gambar 3. Grafik rerata luas daun tanaman sawi hijau.

Keterangan : Angka yang diikuti huruf yang sama pada kategori waktu yang tidak berbeda nyata pada uji lanjut DMRT 5\%. D0 $=0 \mathrm{~g} / \operatorname{tanaman}$ (kontrol), D1 $=100 \mathrm{~g} / \tan a m a n, D 2=$ $150 \mathrm{~g} /$ tanaman, D3 = $200 \mathrm{~g} /$ tanaman. HST $=$ Hari Setelah Tanam.

Secara umum, perlakuan dosis pupuk kompos dari limbah KJP memberikan pengaruh yang lebih baik terhadap parameter luas daun tanaman sawi dibandingkan perlakuan kontrol (tanpa kompos). Berdasarkan hasil uji lanjut DMRT 5\%, perlakuan D3 (200 g/tanaman) menunjukkan rerata luas daun terbaik, yaitu $1332.07 \mathrm{~cm}^{2}$. Hasil ini tidak berbeda nyata dengan perlakuan D2 (150 g/tanaman) dengan luas daun rata- 
rata $1304.56 \mathrm{~cm}^{2}$. Akan tetapi, kedua perlakuan tersebut berbeda nyata dengan hasil perlakuam D1 (100 g/tanaman) dengan luas daun rata-rata $1155.68 \mathrm{~cm}^{2}$, dan perlakuan kontrol (tanpa kompos) dengan luas daun rata-rata $764.75 \mathrm{~cm}^{2}$.

Menurut White et al. (2015), daun merupakan tempat berlangsungnya fotosintesis dimana terdapat berbagai perangkat fotosintesis kompleks yang kaya enzim di dalamnya. Klorofil, stomata, maupun perangkat fotosintesis lainnya tersusun atas senyawa organik, sehingga keberadaannya tidak terlepas dari peranan unsur hara, baik sebagai komponen integral maupun sebagai kofaktor enzim dalam proses biosintesisnya (Weissert dan Kehr, 2017).

Seperti halnya unsur N, sebanyak $10-50 \%$ kandungan N pada daun ditemukan dalam enzim Rubisco (Ribulose 1.5-bisphosphate carboxylase) yang berperan dalam fiksasi karbon pada siklus Calvin (White et al., 2015). Unsur P berperan dalam meregulasi sintesis pati dan translokasi fotosintat dari kloroplas (Hawkesford et al., 2012). Sedangkan unsur $\mathrm{K}$ bertanggung jawab dalam mempertahankan kadar air relatif daun melalui pengaturan tekanan osmotik, sehingga aktivitas fotosintesis dan translokasi fotosintat berjalan dengan baik (Lone dan Khan, 2007).

Berdasarkan hal tersebut, proses metabolik tanaman terutama fotosintesis sangat dipengaruhi oleh jumlah ketersediaan unsur hara. Hasil penelitian Iqbal et al. (2011) membuktikan bahwa peningkatan dosis N mampu meningkatkan karakteristik fotosintesis seperti laju fotosintesis, konduktansi stomata, efisiensi penggunaan air, aktivitas enzim Rubisco, konsentrasi $\mathrm{CO}_{2}$ intraseluler, serta luas daun dan bobot kering tanaman sawi hijau. Hal ini membuktikan bahwa pemberian kompos limbah KJP dapat meningkatkan ketersediaan hara di dalam tanah, sehingga dapat mendukung proses fotosintesis dan proses metabolik tanaman secara keseluruhan. Dosis kompos yang lebih tinggi terbukti dapat meningkatkan luas daun tanaman sawi hijau.

Selain faktor jumlah ketersediaan unsur hara, peningkatan luas daun juga dipengaruhi oleh karakteristik kompos yang memungkinkan penyerapan unsur hara tersebut berlangsung dengan baik. Berdasarkan pembahasan sebelumnya, karakteristik pupuk kompos antara lain: (1) mampu memperbaiki struktur tanah menjadi gembur, (2) meningkatkan aerasi tanah dan menahan air lebih lama, (3) meningkatkan KTK tanah dengan kandungan koloid humus dan asam-asam organik, (4) meningkatkan aktivitas mikroorganisme dengan bahan organik yang tinggi, dan

(5) mampu menekan kehilangan hara karena pencucian dan/atau volatilisasi (Hairiah et al., 2002; Setyorini et al., 2006; Yulia et al., 2011).

Secara umum, pertumbuhan dan perkembangan daun yang terhambat terlihat pada perlakuan kontrol (tanpa kompos). Gejala yang tampak secara visual yaitu luas daun yang lebih sempit dan jumlah daun yang lebih sedikit dibandingkan dengan perlakuan kompos.

\section{Bobot Basah}

Bobot basah merupakan parameter yang menunjukkan hasil akhir dari proses fisiologi tanaman. Berdasarkan hasil sidik ragam pada taraf signifikansi $5 \%$, perlakuan 
dosis kompos limbah KJP menunjukkan pengaruh yang signifikan terhadap parameter bobot basah dengan nilai sig. $0.00<\alpha 5 \%$ (Lampiran 7). Oleh karena itu, dilakukan uji lanjut DMRT pada taraf signifikansi 5\% untuk melihat jenis perlakuan dosis kompos yang berbeda nyata. Hasil pengamatan terhadap rerata bobot basah tanaman sawi hijau beserta hasil uji lanjut DMRT disajikan pada Gambar 4.

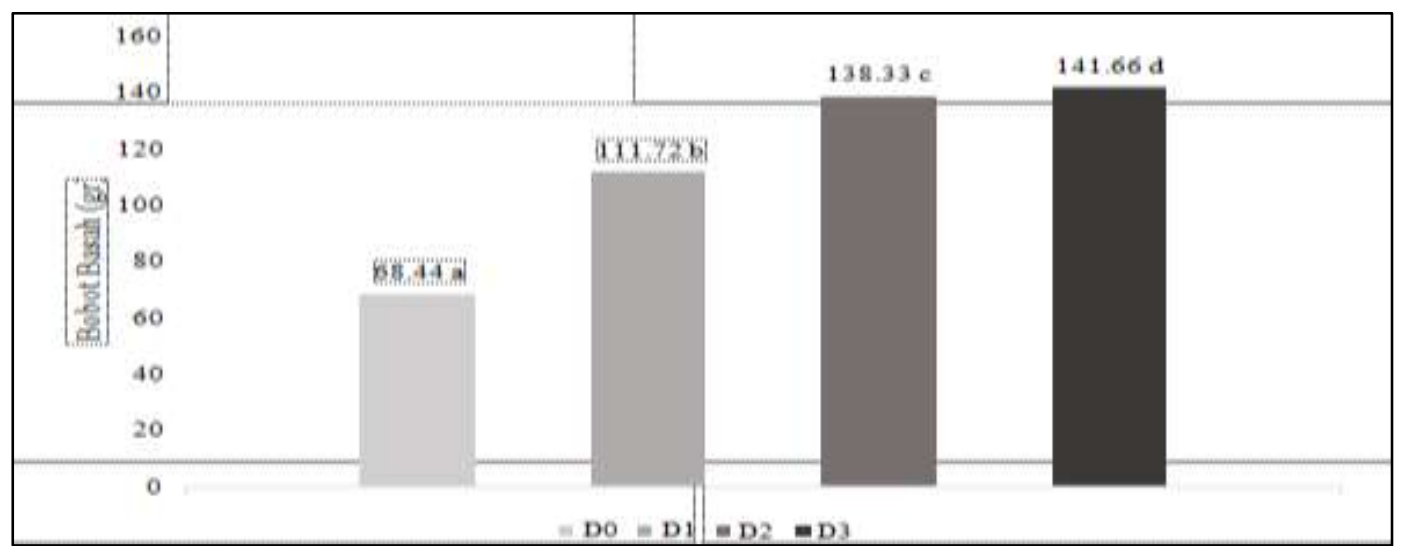

Gambar 4. Grafik rerata bobot basah tanaman sawi hijau.

Keterangan : Angka yang diikuti huruf yang sama pada kategori waktu yang tidak berbeda nyata pada uji lanjut DMRT 5\%. D0 $=0 \mathrm{~g} / \tan a m a n$ (kontrol), D1 $=100 \mathrm{~g} / \operatorname{tanaman}, \mathrm{D} 2=$ $150 \mathrm{~g} /$ tanaman, D3 = $200 \mathrm{~g} /$ tanaman. HST $=$ Hari Setelah Tanam.

Secara umum, perlakuan dosis pupuk kompos dari limbah KJP memberikan pengaruh yang lebih baik terhadap parameter bobot basah dibandingkan perlakuan kontrol (tanpa kompos). Berdasarkan hasil uji lanjut DMRT 5\%, perlakuan D3 (200 $\mathrm{g} /$ tanaman) menunjukkan rerata bobot basah terbaik, yaitu $141.66 \mathrm{~g}$. Hasil ini berbeda nyata dengan perlakuan D2 (150 g/tanaman) dengan bobot rata-rata 138.33 g, perlakuam D1 (100 g/tanaman) dengan bobot rata-rata $111.72 \mathrm{~g}$, dan perlakuan kontrol (tanpa kompos) dengan bobot rata-rata $68.44 \mathrm{~g}$.

Pada dasarnya, perbedaan bobot basah tanaman sawi hijau dipengaruhi oleh kemampuan tanaman dalam membentuk biomassa sebagai hasil penyesuaiannya terhadap lingkungan. Menurut Lynch et al. (2012), mekanisme penyerapan nutrisi serta penggunaannya dikendalikan oleh faktor genetik dan penyesuaian tanaman terhadap lingkungan. Pengaruh perlakuan dosis kompos limbah KJP hanya terbatas pada sumbangan hara, serta perbaikan beberapa aspek fisik, kimia, dan biologi tanah. Selanjutnya, tanaman akan memanfaatkan kondisi tersebut untuk menunjang pertumbuhannya melalui berbagai proses metabolik.

Hubungan source and sink (sumber dan penerima) antara tajuk dengan akar sangat menentukan pembentukan biomassa tanaman. Tajuk (terutama daun) berperan sebagai penyuplai (source) karbon (fotosintat) ke bagian akar sekaligus sebagai penerima (sink) air dan unsur hara dari akar. Sebaliknya, akar berperan sebagai penyuplai air dan unsur hara ke bagian tajuk sekaligus sebagai penerima fotosintat dari tajuk (White et al., 2015). Kedua fungsi tersebut saling mempengaruhi satu sama lain dalam pembentukan biomassa tanaman. Oleh karena itu, segala faktor 
yang dapat mempengaruhi fotosintesis termasuk ketersediaan air dan unsur hara akan mempengaruhi produktivitas tanaman (Lynch et al., 2012).

Kompos limbah KJP mengandung 1-4\% N, 0.1-0.7\% P, dan 5-14\% K. Secara teknis, pemberian dosis kompos 40 ton/ha (200 g/tanaman) telah mencukupi kebutuhan tanaman sawi hijau. Karakteristik kompos yang lambat dalam pelepasan unsur hara memungkinkan unsur hara tersedia selama masa pertumbuhan tanaman (Setyorini et al., 2006). Selain itu, kompos dapat memperbaiki sruktur tanah menjadi gembur dan mempertahankan kelembapan tanah lebih lama, sehingga penyerapan unsur hara berlangsung dengan baik (Wahyono, 2010). Selanjutnya, tanaman akan mengatur alokasi asimilat (fotosintat) antara tajuk dan akar untuk mencapai keseimbangan fungsional antara tajuk sebagai sumber karbon dan akar sebagai sumber air dan unsur hara (Lynch et al., 2012).

Penelitian mengenai pengaruh dosis kompos terhadap tanaman sawi hijau juga telah dilakukan oleh Opposunggu et al. (2017). Hasil penelitian menunjukkan bahwa jumlah daun, luas daun, dan bobot basah tanaman sawi meningkat seiring dengan peningkatan dosis kompos. Pernyataan ini juga didukung oleh hasil penelitian Astria dan Suntari (2017) yang menyatakan bahwa ketersediaan hara N, P, dan K berkolerasi positif dengan peningkatan jumlah daun, luas daun, dan bobot basah tanaman sawi hijau.

Secara umum, produktivitas tanaman sawi hijau yang rendah terlihat pada perlakuan kontrol (tanpa kompos). Gejala yang tampak secara visual yaitu volume tanaman yang lebih kecil dibandingkan perlakuan kompos, serta dilihat dari hasil penimbangan terhadap bobot basah tanaman.

\section{PENUTUP}

\section{Kesimpulan}

Berdasarkan hasil penelitian, dapat disimpulkan bahwa perlakuan dosis kompos limbah jarak pagar (KJP) berpengaruh secara signifikan terhadap seluruh parameter penelitian. Perlakuan D2 (150 g/tanaman) memberikan hasil terbaik dengan rerata tinggi tanaman $37.94 \mathrm{~cm}, 11.88$ helai daun, luas daun $1304.56 \mathrm{~cm}^{2}$, dan bobot basah rata-rata $138.33 \mathrm{~g}$.

\section{Saran}

Berdasarkan kondisi di lapangan dan pertimbangan penulis terhadap penelitian ini, penulis menyampaikan beberapa saran sebagai berikut:

1. Diperlukan penelitian lebih lanjut mengenai efektivitas bakteri atau fungi lignoselulolitik sebagai mikroorganisme dekomposer limbah KJP.

2. Diperlukan uji laboratorium terhadap karakteristik fisiokimia dan biokimia pupuk kompos limbah KJP.

3. Diperlukan penelitian lebih lanjut mengenai pengaruh dosis pupuk kompos limbah KJP pada pertanaman di dataran tinggi. 
4. Diperlukan penelitian lebih lanjut mengenai pengaruh dosis pupuk kompos limbah KJP terhadap tanaman pada musim tanam kedua dan/atau musim tanam berikutnya.

5. Diperlukan penelitian lebih lanjut mengenai kombinasi pupuk kompos limbah KJP dengan pupuk kimia sintetis untuk memaksimalkan efisiensi penggunaan pupuk.

\section{DAFTAR PUSTAKA}

Agustina, L., R. Intan, dan U. K. Koestiharti. (2012). Intercropping Sweet Corn (Zea mays Saccharata Sturt) and Pakchoy (Brassica juncea) in the Different Organic Matter Compositions. Journal of Agriculture and Food Technology. 2 (2): 35-40.

Apriliani, I. N., S. Heddy, dan N. E. Suminarti. (2016). Pengaruh Kalium pada Pertumbuhan dan Hasil Dua Varietas Tanaman Ubi Jalar (Ipomea batatas (L.) Lamb.). Jurnal Produksi Tanaman. 4 (4): 264-270.

Arrasyid, B. (2016). Aplikasi Kompos Kulit Buah Jarak Pagar sebagai Sumber Kalium pada Budidaya Tanaman Jagung Manis (Zea mays saccharata Sturt). Seminar Hasil Penelitian. Fakultas Pertanian. Universitas Muhammadiyah Yogyakarta.

Astria, P. dan R. Suntari. (2017). Aplikasi Urea dan Kompos Kulit Kakao untuk Meningkatkan Ketersediaan dan Serapan N, P, K, serta Produksi Tanaman Sawi pada Inceptisol Tulungrejo, Batu. Jurnal Tanah dan Sumberdaya Lahan. 4 (1): 453-461.

Cartea, M. E., M. Lema, M. Francisco, dan P. Velasco.( 2011). Basic Information on Vegetable Brassica Crops. Dalam: Genetics, Genomics and Breeding of Vegetable Brassicas. New Hampshire: Science Publish. Hlm. 1-30.

Dehgan, B. (1984). Phylogenetic Significance of Interspecific Hybridization in Jatropha (Euphorbiaceae). Dalam Heller, J. (1996). Physic Nut. Jatropha curcas L. Promoting the Conservation and Use of Underutilized and Neglected Crops. Rome: International Plant Genetic Resources Institute.

Diaz, L.F. dan G.M. Savage. (2007). Factors that Affect the Process. Dalam: Compost Science and Technology. Diaz, L.F., M. de Bertoldi, dan W. Bildlingmaier (ed.). 8 (4): 49-65.

Dwiyanty, E. (2011). Kajian Rasio Karbon terhadap Nitrogen (C/N) pada Proses Pengomposan dengan Perlakuan Aerasi dalam Pemanfaatan Abu Ketel dan Sludge Industri Gula. Skripsi. Fakultas Teknologi Pertanian. Institut Pertanian Bogor.

Fauziah, S. (2011). Pengaruh Pupuk Organik pada Produksi dan Serapan Hara Tanaman Caisim (Brassica juncea) Varietas Tosakan pada Latosol Darmaga. Skripsi. Fakultas Pertanian. Institut Pertanian Bogor.

Grzebisz, W., A. Gransee, W. Szczepaniak, dan J. Diatta. (2013). The Effect of Potassium Fertilization on Water-Use Eficiency in Crop Plants. Journal of Plant Nutrition and Soil Science. Hlm. 335-374. 
Gudeta, T. B. (2016). Chemical Composition, Bio-Diesel Potential and Uses of Jatropha curcas L. (Euphorbiaceae). American Journal of Agriculture and Forestry. 4 (2): $35-48$.

Hairiah, K., S. R. Utami, B. Lusiana, dan M. van Noordwijk. (2002). Neraca Hara dan Karbon dalam Sistem Agroforestri. Bahan Ajar. Hlm. 105-136.

Hawkesford, M. W. Horst, T. Kichey, H. Lambers, J. Schjoerring, I. S. Moler, dan P. White. (2012). Function of Macronutrients. Dalam: Marschner's Mineral Nutrition of Higher Plants. Marschner, P. (ed.). Adelaide: Academic Press. Hlm. 135-189.

Heller, J. (1996). Physic Nut. Jatropha curcas L. Promoting the Conservation and Use of Underutilized and Neglected Crops. Rome: International Plant Genetic Resources Institute.

Indriyani, N., T. Wardiyati, dan M. Nawawi. (2018). Pengaruh Macam Pupuk Kandang terhadap Pertumbuhan dan hasil Tanaman Brassica rapa L. dan Brassica juncea L. Jurnal Produksi Tanaman. 6 (5): 734-741.

Iqbal, N., R. Nazar, S. Syeed, A. Masood, dan N. A. Khan. (2011). Exogenouslysourced Ethylene Increases Stomatal Conductance, Photosynthesis, and Growth Under Optimal and Deficient Nitrogen Fertilization in Mustard. Journal of Experimental Botany. 62 (14): 4955-4963.

Kurniawati, A. (2016). Kajian Produksi Sawi Hijau (Brassica juncea) Organik pada Pergiliran Tanaman Jagung dan Kedelai Serta Dosis Pupuk Kandang. Tesis. Sekolah Pascasarjana. Institut Pertanian Bogor.

Kurniawati, F. (2018). Pengujian Kualitas Kompos di Kebun Raya Cibodas terhadap Pertumbuhan Sawi Hijau (Brassica rapa). Jurnal Hortikultura Indonesia. Vol 9 (1): 47-53.

Lakitan, B. (2015). Dasar-dasar Fisiologi Tumbuhan. Jakarta: PT Raja Grafindo Persada.

Lima, R. L. S., V. Sofiatti, C. A. V. Azevedo, J. O. Cazetta, G. S. C. Júnior, dan N. H. C. Arriel. 2014. Nutrient Accumulation Curves in Fruits and Nutrient Export by Seeds and Hulls Harvesting of Physic Nut (Jatropha curcas L.). Semina-Ciências Agrárias. 35: 3003-3014.

Lone, P. M. dan N. A. Khan. (2007). The Effect of Rate and Timing of N Fertilizer on Growth, Photosynthesis, N Accumulation and Yield of Mustard (Brassica Juncea) Subjected to Defoliation. Environtmental and Experimental Botany. Hlm. 318-323.

Lynch, J., P. Marschner, dan Z. Rengel. (2012). Effect of Internal and External Factors on Root Growth and Development. Dalam: Marschner's Mineral Nutrition of Higher Plants. Marschner, P. (ed.). Adelaide: Academic Press. Hlm. 331-346.

Marschner, P. (2012). Rhizosphere Biology. Dalam: Marschner's Mineral Nutrition of Higher Plants. Marschner, P. (ed.). Adelaide: Academic Press. Hlm. 369- 388. 
McGrath, J. M., J. Spargo, dan C. J. Penn. (2014). Soil Fertility and Plant Nutrition. Encyclopedia of Agriculture and Food System. Alfen, N. V. (ed.). Vol. 5 Hlm. 166184.

Mitra, G. N.(2015). Regulation of Nutrient Uptake by Plants. Department of Soil Science and Agricultural Chemistry. Orissa University of Agriculture and Technology.

Mitra, G. N. (2017). Essential Plant Nutrients and Recent Concepts about Their Uptake. Dalam: Essential Plant Nutrients. Naeem, M., A. A. Ansari, dan S.

S. Gill (ed.). Cham: Springer International Publishing AG. Hlm. 1-36.

NRCS (Natural Resources Conservation Service). (2011). Carbon to Nitrogen Ratios in Cropping System. United States Department of Agriculture (USDA). Greensboro.

NRCS (Natural Resources Conservation Service). (2020). Brassica parachinensis

L. H. Bailey. Plant Database. United States Department of Agriculture (USDA). https://plants.usda.gov/core/profile?symbol=BRPA13

NRCS (Natural Resources Conservation Service). (2020). Jatropha curcas L. Plant Database. United States Department of Agriculture (USDA). https://plants.usda.gov/core/profile?symbol=JACU2

Opposunggu, R. P., N. Soverda, dan E. I. Swari. (2017). Respon Tanaman Sawi (Brassica juncea L.) terhadap Pemberian Kompos Sampah Kota. Artikel Ilmiah. Fakultas Pertanian. Universitas Jambi.

Primandari, S. R. P., A. K. M. A. Islam, Z. Yaakob, dan S. Chakrabarty. (2018). Jatropha curcas L. Biomass Waste and Its Utilization. Dalam: Advances in Biofuels and Bioenergy. Hlm. 273-282.

Santoso, B. B. (2010). Deskripsi Botani Jarak Pagar. Jatropha curcas L. Lombok Barat: Arga Puji Press.

Sensus Pertanian. (2013). Jumlah Rumah Tangga Usaha Hortikltura, Luas Tanam, dan Rata-rata Luas Tanam yang Diusabakan Menurut Jenis Tanaman Hortikultura Semusim. Badan Pusat Statistik Republik Indonesia. https://st2013.bps.go.id/dev2/index.php

Setyorini, D., R. Saraswati, dan E. K. Anwar. (2006). Kompos. Dalam: Pupuk Organik dan Pupuk Hayati. Simanungkalit, R. D. M., D. A. Suriadikarta, R. Saraswati, D. Setyorini, dan W. Hartatik (ed.). Balai Besar Penelitian dan Pengembangan Sumberdaya Lahan Pertanian. Hlm. 11-40.

Sharma, D. K., A. K. Pandey, dan Lata. (2009). Use of Jatropha curcas Hull Biomass for Bioactive Compost Production. Biomass and Bioenergy. 33: 159-162.

Subardja, D., S. Ritung, M. Anda, Sukarman, E. Suryani, R. E. Subandiono. (2014). Petunjuk Teknis Klasifikasi Tanah Nasional. Balai Besar Penelitian dan Pengembangan Sumberdaya Lahan Pertanian.

Suwarno, M. (2011). Respon Tanaman Jagung (Zea mays L.) terhadap Aplikasi Pupuk Organik dari Limbah Kulit Buah Jarak pagar (Jatropha curcas L.) yang Diinkubasi dengan 4 Jenis Biodekomposer. Skripsi. Fakultas Pertanian. Institut Pertanian Bogor. 
Wahyono, S. (2010). Tinjauan Manfaat Kompos dan Aplikasinya pada Berbagai Bidang Pertanian. Jumal Rekayasa Lingkungan. Balai Pengkajian dan Penerapan Teknologi. Jakarta.6 (1): 29-38.

Weissert, C. dan J. Kehr. (2018). Macronutrient Sensing and Signaling in Plants. Dalam: Plant Macronutrient Use Efficiency. Hossain, M. A., T. Kamiya, D.

J. Burrit, L. P. Tran, dan T. Fujiwara (ed.). Hlm. 45-64.

White, A. C., A. Rogers, M. Rees, dan C. P. Osborne. (2015). How Can We Make Plants Grow Fast? A Source-Sink Perspective on Growth Rate. Journal of Experimental Botany. 67 (1): 31-45.

Yulia, A.E., Murniati, dan Fatimah. (2011). Aplikasi Pupuk Orgnaik pada Tanaman Caisim untuk Dua Kali Penanaman. Dalam: Sagu. 10 (1): 14-19. 